Materiales de Construcción

Vol. 69, Issue 333, January-March 2019, e175

ISSN-L: 0465-2746

https://doi.org/10.3989/mc.20198.12517

\title{
Development of lightweight insulating building materials from perlite wastes
}

\author{
G.M. Tsaousi $\bowtie$, L. Profitis, I. Douni, E. Chatzitheodorides, D. Panias \\ National Technical University of Athens (NTUA), (Athens, Greece) \\ $\triangle$ margitsaousi@metal.ntua.gr
}

Received 23 November 2017

Accepted 28 May 2018

Available on line 22 January 2019

\begin{abstract}
This paper investigates the development of geopolymer foam boards, using perlite wastes as raw material. This type of lightweight materials combines the geopolymerization technology with the foaming process. The mechanism of foaming is based on the generation of a gas that is retained by the geopolymer matrix in the form of individual or interconnected voids. In this study, the inorganic foaming agent is hydrogen peroxide $\left(\mathrm{H}_{2} \mathrm{O}_{2}\right)$, which is added into the initial paste in different quantities by mechanical stirring. The produced porous materials have effective densities between $408-476.5 \mathrm{~kg} / \mathrm{m}^{3}$, thermal conductivities between $0.076-0.095 \mathrm{~W} / \mathrm{m} . \mathrm{K}$ and different type of microstructure, depending on the concentration of the activator and the foaming agent content. To assess the porosity and the size distribution of the voids, image processing techniques were applied on digital images of the samples. According to these results, the synthesized lightweight materials exhibit similar or even better thermal properties than the current concrete porous materials.
\end{abstract}

KEYWORDS: Geopolymerization; Foaming; Inorganic; Lightweight

Citation/Citar como: Tsaousi, G.M.; Profitis, L.; Douni, I.; Chatzitheodorides, E.; Panias, D. (2019) Development of lightweight insulating building materials from perlite wastes. Mater. Construcc. 69 [333], e175 https://doi.org/10.3989/ mc.2019.12517

RESUMEN: Desarrollo de materiales de construcción aislantes ligeros a partir de desechos de perlita. Este documento investiga el desarrollo de tableros de espuma de geopolímero, utilizando residuos de perlita como materia prima. Este tipo de materiales ligeros combina la tecnología de geopolimerización con el proceso de formación de espuma. El mecanismo de formación de espuma se basa en la generación de un gas retenido por la matriz del geopolímero en forma de vacíos individuales o interconectados. En este estudio, el agente espumante inorgánico es el peróxido de hidrógeno $\left(\mathrm{H}_{2} \mathrm{O}_{2}\right)$, que se agrega a la pasta inicial en diferentes cantidades mediante agitación mecánica. Los materiales porosos producidos tienen densidades efectivas entre $408-476.5 \mathrm{~kg} / \mathrm{m}^{3}$, conductividades térmicas entre $0.076-0.095 \mathrm{~W} / \mathrm{m} . \mathrm{K}$ y diferentes tipos de microestructura, dependiendo de la concentración del activador y el contenido del agente espumante. Para evaluar la porosidad y la distribución de tamaños de los vacíos, se aplicaron técnicas de procesamiento de imágenes en las imágenes digitales de las muestras. De acuerdo con estos resultados, los materiales ligeros sintetizados exhiben propiedades térmicas similares o incluso mejores que los materiales porosos de hormigón actuales.

PALABRAS CLAVE: Geopolimerización; Espumoso; Inorgánico; Ligero

ORCID ID: G.M. Tsaousi (http://orcid.org/0000-0002-4985-968X); L. Profitis (http://orcid.org/0000-0002-9686-4449); I. Douni (http://orcid.org/0000-0001-9602-5429); E. Chatzitheodorides (http://orcid.org/0000-0003-1180-5456); D. Panias (http://orcid.org/0000-0002-0432-6900)

Award-winning paper at II European Geopolymer Network. Madrid, 14th July, 2017

Copyright: (C) 2019 CSIC. This is an open-access article distributed under the terms of the Creative Commons Attribution 4.0 International (CC BY 4.0) License. 


\section{INTRODUCTION}

A review of the embodied energy values (the sum of the amount of energy required to fabricate a product) shows that most of the commonly used insulating materials in the construction industry exhibit high values $(45-138 \mathrm{MJ} / \mathrm{kg})(1-3)$. This, mainly results either from the energy-intensive conditions used during manufacturing of the mineral-based insulating materials, or from the high embodied energy values during the production of oil-based raw materials. Moreover, contemporary insulating materials can suffer from various disadvantages, including degrading thermal and acoustic performance, combustibility, shrinkage and pollution of the indoor building environment. The objective of the project is to develop a new generation of inorganic insulating materials that can be used as masonry components.

In the last few years, lightweight cellular masonry materials find great applications in the construction sector, with autoclaved aerated concrete (AAC) and foam concrete (FC) currently leading the market. AAC is made from naturally occurring materials that are found in abundance, such as lime, fine sand, other siliceous materials, water and a small amount of aluminum powder (manufactured as a by-product of aluminum production). Cement is also added, in order to produce low density materials, similar to the conventional building materials (4).

AAC is produced by foaming Portland Cement (OPC) with the use of hydrogen gas that is generated from aluminum powder addition (5). Even though AAC production suffers from some disadvantages, such as the requirement for increased plant precautions due to the explosive nature of hydrogen gas, as well as difficulties in the production control and high energy consumption (5-9).

On the other hand, the production line of FC is quite simple and easy to control, as raw materials are very common and required equipment for their fabrication includes only a truck mixer and an extruder. Still, the use of FC has some disadvantages, such as its sensitivity to water content and its difficulty to be placed and finished due to the porosity and angularity of the aggregate. In some mixes the cement mortar may separate the aggregate and float towards the surface. Furthermore, the mixing time required is longer than that of the conventional concrete (10). Finally, FC presents low compressive strength values for its apparent density and thermal conductivity levels.

Geopolymer foam boards coming from industrial wastes seem to be very attractive as alternatives of the autoclaved aerated concrete and foam concrete, with significant technical benefits (i.e., improved chemical and fire resistance) (11). The geopolymerization process is based on an exothermic heterogeneous chemical reaction between a solid aluminosilicate raw material and an alkali metal silicate solution, under mild conditions $(12,13)$. The foaming process aims ideally at forming a large number of small individual voids (closed cells) or interconnected networks of voids (open cells) inside a viscous material (i.e., a paste or a polymer). The control of the nature, size and distribution of voids, is the most critical step in the production of foamy materials, specifying their final density and strength (14). Voids can be produced by two methods: 1) by introducing a very large volume fraction of air bubbles (15), usually through the use of surfactants, 2) by endogenous gas generation, which can be achieved by mixing gas-releasing agents, such as aluminum powder or hydrogen peroxide, in a cement like paste or a mortar. Hydrogen peroxide $\left(\mathrm{H}_{2} \mathrm{O}_{2}\right)$ is a widely known inorganic foaming agent which is thermodynamically unstable and therefore can be easily decomposed to water and oxygen gas [eq.1], with the latter playing the role of the blowing agent (16) [1].

$$
2 \mathrm{H}_{2} \mathrm{O}_{2} \rightarrow 2 \mathrm{H}_{2} \mathrm{O}+\mathrm{O}_{2}
$$

The synthesis of low density geopolymers using hydrogen peroxide is influenced by the optimization of the kinetics of peroxidede composition with production of oxygen and the increase in viscosity of the geopolymer paste (17).

Alumina powder is also a famous foaming agent which reacts with water and hydroxide in an alkaline environment, liberating bubbles of hydrogen gas and forming hydrolyzed metal complexes. This takes place according to a reaction similar to the equation [eq.2] below (18):

$$
\mathrm{Al}+3 \mathrm{H}_{2} \mathrm{O}+\mathrm{OH}^{-} \rightarrow \mathrm{Al}(\mathrm{OH})^{-4}+\frac{3}{2} \mathrm{H}_{2}
$$

The release of the aforementioned gases, contributes to pores formation prior to the hardening of the geopolymer pastes leading to materials with high overall porosity and low density values after the appropriate curing process. The final hardened structures present good mechanical and thermal properties, and can therefore be used for applications in acoustic panels and in lightweight pre-fabricated components for thermal insulation purposes. Nevertheless, hydrogen peroxide has been proved as the foaming agent that under specific conditions results in materials with lower thermal conductivity values (17).

In this study, geopolymer pastes were foamed by using hydrogen peroxide as the blowing agent. The effect of the foaming agent's content on the final foam board's characteristics was extensively studied. In order to determine the frequency of specific size voids in function of increasing peroxide content, image processing techniques were used. 


\section{EXPERIMENTAL}

\subsection{Materials}

The raw materials used for the synthesis of foam boards, consist of sodium hydroxide, hydrogen peroxide and perlite wastes from the milling plant of Imerys in Milos island, Greece. The chemical analysis in dry basis, determined by a XEPOS X-ray Fluorescence diffractometer utilizing the X-LAB software, is given as oxides in wt.\% in Table 1. Loss on ignition was determined after heating perlite for $1 \mathrm{~h}$ at $1100^{\circ} \mathrm{C}$.

Granulometry of raw perlite waste was measured on a MALVERN Laser Particle Size Analyzer and its mean particle size was determined as $\mathrm{d}_{50}=26$ $\mu \mathrm{m}$. Its specific surface area was measured to 0.65 $\mathrm{m}^{2} / \mathrm{g}$ by a QUANTACHROME Nova-1200 Ver 5.01 porosimeter. Its skeletal density, measured with a QUANTACHROME Stereopycnometer, is $2402 \mathrm{~kg} / \mathrm{m}^{3}$. The mineralogical analysis has shown that the perlite waste is mostly amorphous, with only a small proportion of crystalline phases, such as quartz and feldspars.

The alkaline activator that was used for the synthesis of geopolymer pastes was an aqueous sodium hydroxide solution, prepared by dissolving sodium hydroxide pellets (Merck Chemicals, 99\% purity) in deionized water. Hydrogen peroxide was selected as foaming agent (Merck $\mathrm{H}_{2} \mathrm{O}_{2}$, $30 \% \mathrm{w} / \mathrm{w})$.

\subsection{Paste preparation and foaming}

Geopolymer foams were prepared by mixing perlite with the alkaline activating solution for 20 minutes, until a homogeneous mixture was obtained. The selected $\mathrm{NaOH}$ concentration was 2 and $4 \mathrm{M}$, while the solid/liquid ratio was equal to $2 \mathrm{~g} / \mathrm{mL}$ according to the previous published study of Tsaousi et al (19). Then the hydrogen peroxide was added in the mechanical stirrer, extending the stirring time by 5 more minutes. The amount of added $\mathrm{H}_{2} \mathrm{O}_{2}$ varied between $0.05-1 \% \mathrm{w} / \mathrm{w}$. Then the mixture was molded in $15 \times 15 \times 4 \mathrm{~cm}$ metallic molds and cured in two consecutive stages (stage $1: 70{ }^{\circ} \mathrm{C}$ for $24 \mathrm{~h}$, stage 2: $50{ }^{\circ} \mathrm{C}$ for $96 \mathrm{~h}$ ). The maximum linear shrinkage observed in the final materials was $1 \%$. After curing, the specimens were demolded and kept in a dry atmosphere.

\subsection{Characterization methods}

\subsubsection{Analytical methods}

The resulting materials were evaluated for their thermophysical properties. Thus, the apparent density $d$ of the foam boards was calculated using the equation: $d=m / V$, where $m=$ weight of the board, and $V=$ volume of the board. In order to achieve smooth and uniform dimensions appropriate for further evaluation (microstructure study), the measurement took place after cutting the final materials using a band saw. The thermal conductivity of foam boards was also estimated using a Netzsch HFM 436/3 Lamda heat flow meter. Compressive strength measurements of the geopolymer foams were also performed on specimens cut at $4 \mathrm{~cm}$ width and at a thickness of between $0.8-3 \mathrm{~cm}$ (Instron 4482; in accordance with the standard C 109/C 109M-02). Finally, the microstructure study of the porous materials performed using a scanning electron microscope-JEOL6380LV.

\subsubsection{Image processing methods}

Image processing techniques were used to characterize the voids size and distribution as a function of peroxide concentration. The digital images were acquired from the saw-cut flat surfaces of the geopolymer boards, using a commercial scanner at high resolution. A new circle detection software algorithm was developed to analyze each void to its constituent circular bubbles. This void detection algorithm was highly optimized to minimize the irregularities of the void boundaries. In fact, it is partly based on known methodologies in the literature, such as the well-known Circle Hough Transform (20-22) but solves inconsistencies of existing circle-detection algorithms (23-27).

According to the above mentioned method, flat polished surfaces of all samples were colored by masking only the voids boundaries. These surfaces were then scanned with a nominal resolution of 600 $\times 600$ dpi (dots per inch) using a commercially available scanner (pixel size was about $40 \mu \mathrm{m}^{2}$ ). Digital image processing was then used to segment the redhued flat surface of the sample from its voids.

Briefly, the void detection was performed in two processing stages. In the first stage, the k-means clustering method (28) and the Euclidean distance between pixels were used to separate red-hued void boundaries from the grey void volumes (Figure 1a),

TABLE 1. Chemical analysis of perlite waste.

\begin{tabular}{lcccccccc}
\hline \multicolumn{10}{c}{ Oxides (\%) w/w } \\
\hline $\mathrm{Na}_{\mathbf{2}} \mathbf{O}$ & $\mathbf{M g O}$ & $\mathrm{Al}_{\mathbf{2}} \mathbf{O}_{\mathbf{3}}$ & $\mathrm{SiO}_{2}$ & $\mathbf{K}_{\mathbf{2}} \mathbf{O}$ & $\mathbf{C a O}$ & $\mathbf{F e}_{\mathbf{2}} \mathbf{O}_{3}$ & LOI & TOTAL \\
\hline 3.99 & 0.27 & 10.51 & 75.33 & 4.31 & 1.38 & 1.17 & 2.83 & 100 \\
\hline
\end{tabular}



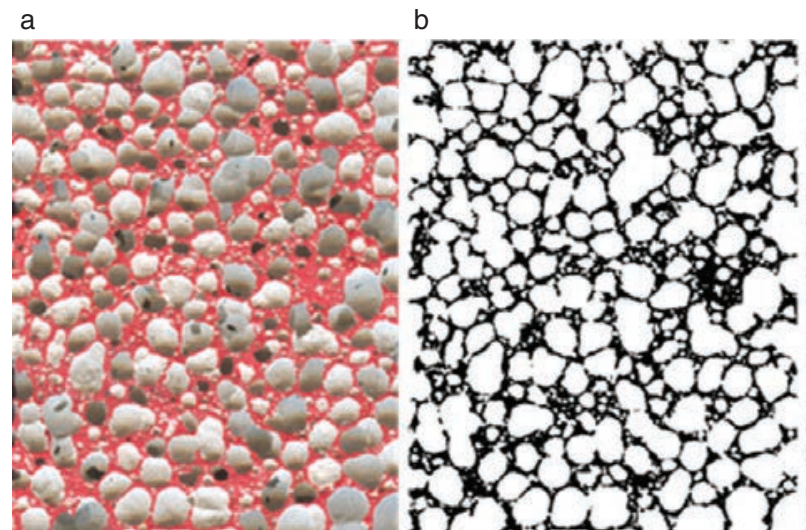

C

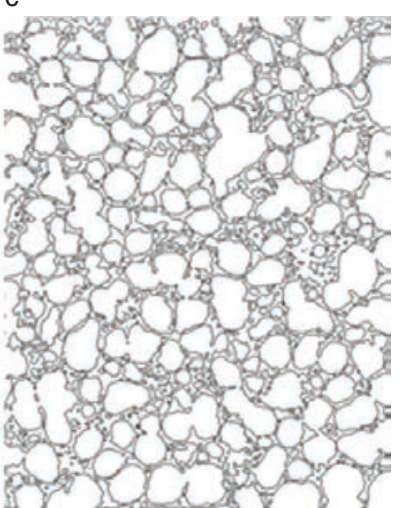

FIGURE 1. First stage of digital processing of the scanned geopolymer foam plates (a) Original red-stained scanned image of the saw-cut flat surface of a sample; (b) binarized representation of the original image, with white representing the voids and with black the flat material matrix; (c) image of the extracted void boundaries.

according to their color and/or brightness which were calculated in the "CIE $L * a * b *$ " color space (often mentioned as "Lab"). Images were then converted to binary format (Figure 1b) and the void boundaries were extracted (Figure 1c).

The second processing stage was the new circledetection algorithm, which uses the void boundary image (Figure 1c) to effectively and quickly extract the size and the number of voids of a time snapshot of the solidified sample. These are extrapolated to the total porosity of the sample of this snapshot, however in two dimensions. Although the algorithm will be presented in detail in a future publication, here, the methodology is briefly described. The complicated boundaries of voids (i.e., often merged circular bubbles) are composed of arcs. The algorithm detects these arcs as part of a circle's circumference, i.e., those that are edges of a void and belong to a circle that is a single circular bubble. The detection algorithm is based on a distance transform in binary image by calculating the Euclidean distance, i.e., the distance between every white pixel and its nearest black pixel (zero value). A "Laplacian of Gaussian" filter is applied on the distance transform image with an optimum size window of $5 \times 5$ pixels and a "sigma" (standard deviation) value of 0.5 , appropriate for the scale and resolution of images, which serves as an edge detection technique to enhance the distance transform image. Maxima suppression filter is then applied on the convolved image and local maxima are detected and stored as candidate points of circle centers. To increase the detection accuracy, an additional filter that selects points belonging to a circle and points to reject as possible noise are computed and stored. This is based on the standard deviation of the candidate points that belong to a circle. The resulting array of candidate circles is then searched and overlapping circles are rejected.
The final step of this processing stage comprises a bubble area readjustment, i.e., the recalculation of the areas of the meniscus-shaped merged bubbles to their original area, as if they would be full circles. This recalculation is made with the use of the circle equation. Remaining non-uniform bubble volumes are also included, after they are recalculated by area to represent perfect circles. The resulting list of bubble sizes is finally plotted as histogram plots of bubble area distributions (Figure 6).

\section{RESULTS AND DISCUSSION}

\subsection{Properties of foamed geopolymers}

Figure 2 depicts the apparent density (a) and thermal conductivity (b) of the foam boards as a function of the content of the foaming agent $\left(\mathrm{H}_{2} \mathrm{O}_{2}\right)$ in the paste for two different sodium hydroxide concentrations ( 2 and $4 \mathrm{M}$ ).

It is observed from Figure 2a that the apparent density decreases substantially as the $\% \mathrm{H}_{2} \mathrm{O}_{2}$ increases up to an optimum value of $0.25 \%$, reaching a value which is slightly higher than $400 \mathrm{~kg} / \mathrm{m}^{3}$ and $450 \mathrm{~kg} / \mathrm{m}^{3}$ for the $2 \mathrm{M}$ and $4 \mathrm{M}$ of $\mathrm{NaOH}$ concentration respectively. Further addition of $\mathrm{H}_{2} \mathrm{O}_{2}$ seems to have insignificant effect on the board's apparent density, reaching a plateau in both cases. Concerning the thermal conductivity of the foam boards (Figure $2 b$ ), the results reveal a similar trend to the apparent density curve, presenting a rapid decrease on thermal conductivity values at low $\mathrm{H}_{2} \mathrm{O}_{2}$ contents $(0.05$ to $0.25 \%)$. In the region between 0.25 and $1 \% \mathrm{H}_{2} \mathrm{O}_{2}$ content, thermal conductivity seems to reach a plateau around $0.08 \mathrm{~W} / \mathrm{mK}$ for $2 \mathrm{M}$ of $\mathrm{NaOH}$ concentration and $0.095 \mathrm{~W} / \mathrm{mK}$ for $4 \mathrm{M}$.

Compressive strength of geopolymer foam specimens ( 2 and $4 \mathrm{M}$ of $\mathrm{NaOH}$ concentration) in 


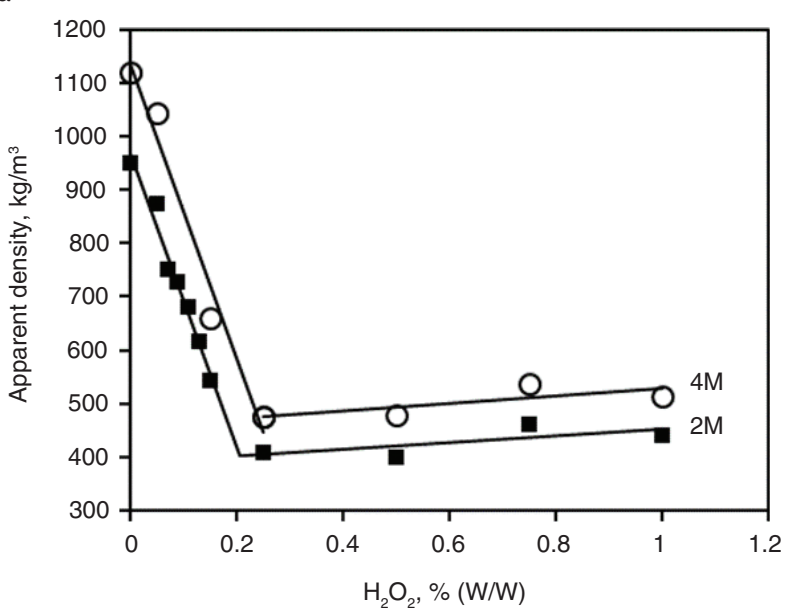

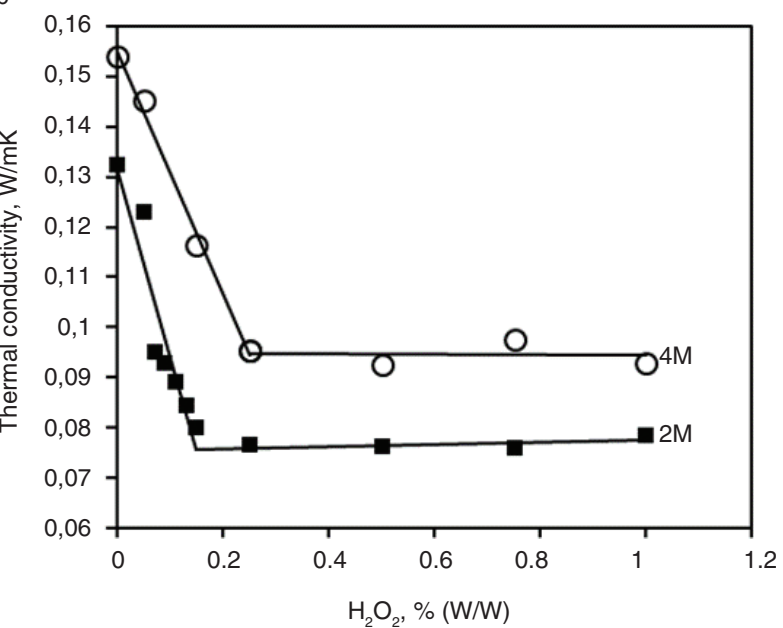

Figure 2. a) Apparent Density and b) Thermal Conductivity of $2 \mathrm{M}$ and $4 \mathrm{M} \mathrm{NaOH}$ foam boards as a function of agent's content in the paste $\left(\mathrm{S} / \mathrm{L}: 2 \mathrm{~g} / \mathrm{mL}\right.$, Curing: $24 \mathrm{~h}$ at $70{ }^{\circ} \mathrm{C}$ and $96 \mathrm{~h}$ at $\left.50{ }^{\circ} \mathrm{C}\right)$

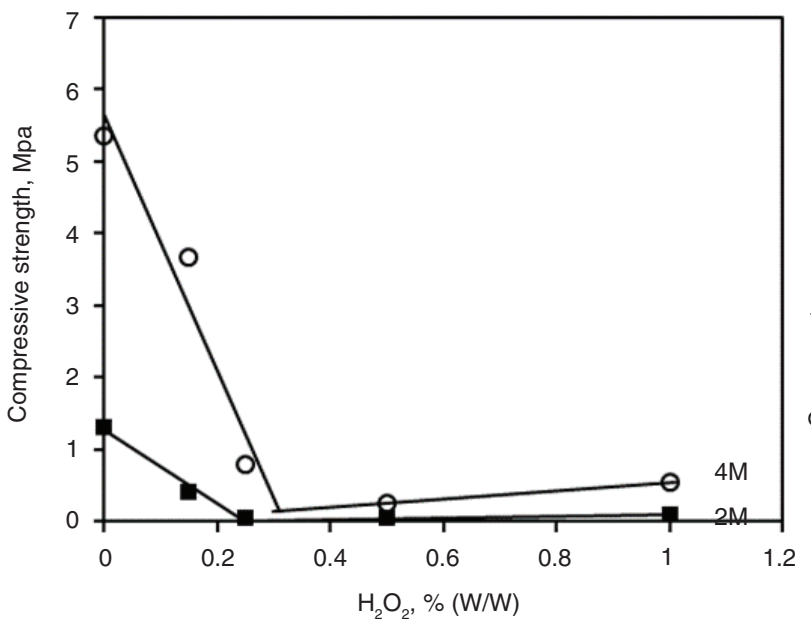

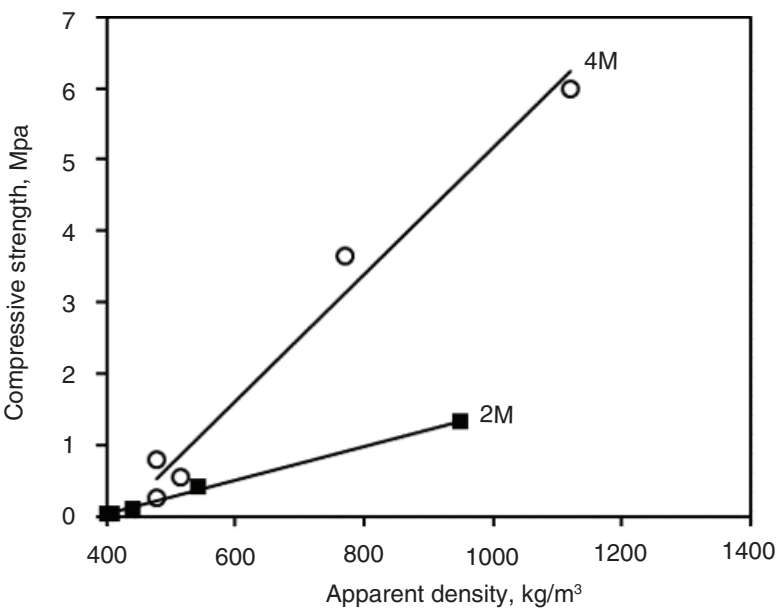

FIgure 3. a) Compressive Strength of the foams as a function of $\% \mathrm{H}_{2} \mathrm{O}_{2}$ in the paste, b) Compressive Strength of the foams as a function of board's density ([NaOH]: 2 and $4 \mathrm{M}, \mathrm{S} / \mathrm{L}: 2 \mathrm{~g} / \mathrm{mL}$, Curing: $24 \mathrm{~h}$ at 70 and $96 \mathrm{~h}$ at $50^{\circ} \mathrm{C}$.)

relation to the initial hydrogen peroxide's concentration, is presented in Figure 3a.

Figure $3 \mathrm{a}$ reveals that the increase of hydrogen peroxide's content up to $0.25 \%$, results in specimens with decreased mechanical strengths for both foam boards with 2 and $4 \mathrm{M}$ of $\mathrm{NaOH}$ concentrations. Further addition of the foaming agent leads to a plateau on the compressive strength values of the foam boards. The same behavior concerning the optimum value of $0.25 \% \mathrm{H}_{2} \mathrm{O}_{2}$, is also observed in the apparent density and thermal conductivity values (Figure $2 \mathrm{a}$ and $\mathrm{b}$ ). The foam boards with $4 \mathrm{M}$ of $\mathrm{NaOH}$ concentration present higher compressive strength values compared to the boards with $2 \mathrm{M}$ $\mathrm{NaOH}$, while at the same time their apparent density and thermal conductivity values are also higher, as indicated by Figure 2. The correlation between the mechanical properties and the apparent density of the boards is also presented in Figure $3 \mathrm{~b}$, showing that the compressive strength increases for higher apparent density values.

The results of Figure $3 \mathrm{a}$ are in accordance with Nambiar and Ramamurthy study (29) where is reported that the addition of high volume of foam, produces materials with decreased density and thus, lower the mechanical strength. Similar behavior concerning the mechanical properties of the materials in function of the concentration of the foaming agent, is also noted in case of fly ash geopolymers and geopolymer foam concrete, as indicated by the studies of Soutsos (30) and Zhang (31) respectively. The results of Figure $3 \mathrm{~b}$ are also confirmed by scientific studies in the literature (32-36) in case of pozzolanic raw materials with different type of foaming 
agents (aluminium powder, hydrogen peroxide, palm oil) where is reported that the compressive strength of the foam boards increases for rising density values, due to the decrease of overall porosity as it will be confirmed by the following microstructure study.

\subsection{Microstructure and porosity of foamed geopolymers}

The above mentioned difference on the properties of 2 and $4 \mathrm{M} \mathrm{NaOH}$ foam boards can be explained by their microstructure study in function of increasing $\% \mathrm{H}_{2} \mathrm{O}_{2}$. The results are presented in Figure 4.

The increase of the $\% \mathrm{H}_{2} \mathrm{O}_{2}$ up to the optimum value of $0.25 \%$, increases the size of cells (Figure $4 \mathrm{a}, \mathrm{b})$ and makes their walls thinner, especially for the case of $2 \mathrm{M}$ of $\mathrm{NaOH}$ concentration. Further increase of $\% \mathrm{H}_{2} \mathrm{O}_{2}$ leads to the perforation of the very thin cell walls causing coalescence of the neighboring cells and collapse of the foamed structure, which has as a consequence the degradation of the board and therefore the slight increase of the apparent density (Figure 3a). The pore sizes in case of foam boards with $4 \mathrm{M}$ of $\mathrm{NaOH}$ concentration range at a lower value compared to $2 \mathrm{M} \mathrm{NaOH}$, resulting in less thin walls (Figure $3 \mathrm{~b}$ ) and thus explaining the higher apparent density and thermal conductivity values followed by improved mechanical properties of these specimens.

The fact that the increase of foaming agent results in materials with lower apparent density values and bigger pore sizes (microstructure study) is also confirmed by Vaou et.al and Tsaousi et.al studies $(37,38)$ focused on the development of geopolymer foams using different origin's perlite wastes and $\mathrm{H}_{2} \mathrm{O}_{2}$ as a foaming agent. At the same time, Masi et.al and Ducman et.al $(17,32)$ confirm the above observations, using fly ash as raw material and hydrogen peroxide, aluminium powder and surfactants as foaming agents.

Digital imaging methods were applied for the estimation of the final porosity of the boards, calculated from the scanned images as a ratio of the cumulative area of the detected voids to the total area of the image. The lower concentration of activator (2 $\mathrm{M} \mathrm{NaOH})$ was selected for digital segmentation of the voids, while the solid to liquid ratio was kept constant at $2 \mathrm{~g} / \mathrm{mL}$ and the added $\% \mathrm{H}_{2} \mathrm{O}_{2}$ varied from $0.05-1 \%$. In Figure 5 the $\%$ cell volume of the final boards is plotted as a function of $\mathrm{H}_{2} \mathrm{O}_{2}$ content through a plot diagram of the above digital imaging methods results, demonstrating the relation between the amount of $\mathrm{H}_{2} \mathrm{O}_{2}$ and the area of porosity, normalized with the total area of the image. Fitting curves have been plotted by using a non-linear regression model for both sets of data. To evaluate the integrity of the digital voids detection, the scanned image of each board was divided into four sub-blocks and ratios were calculated for each sub-block.

The results reveal that the increase of $\mathrm{H}_{2} \mathrm{O}_{2}$ causes a rapid increase on the $\%$ Cell Volume of the geopolymer foams, with a peak point of 72 at $0.25 \%$ of $\mathrm{H}_{2} \mathrm{O}_{2}$, while between $0.25-1 \%$ of the agent,

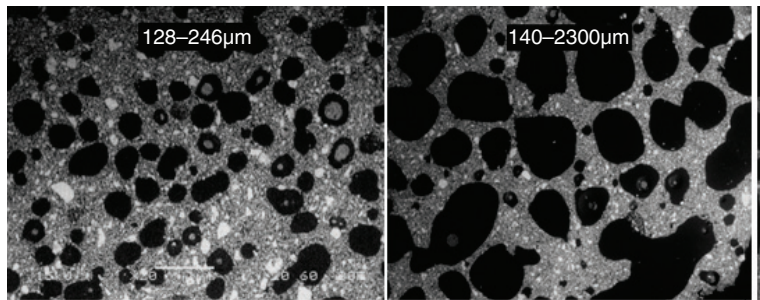

$0,05 \% \mathrm{H}_{2} \mathrm{O}_{2}$
$0,15 \% \mathrm{H}_{2} \mathrm{O}_{2}$

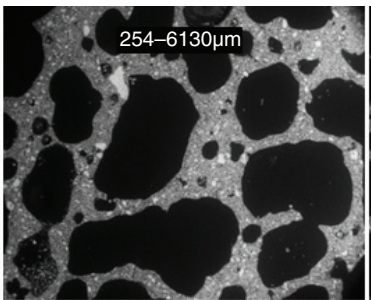

$0.25 \% \mathrm{H}_{2} \mathrm{O}_{2}$

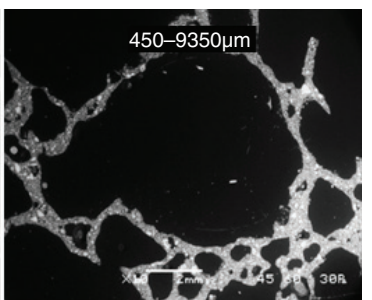

$1 \% \mathrm{H}_{2} \mathrm{O}_{2}$

(a) $2 \mathrm{M}$

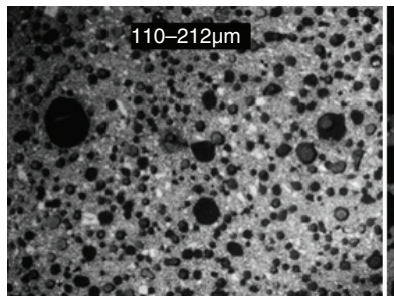

$0,05 \% \mathrm{H}_{2} \mathrm{O}_{2}$

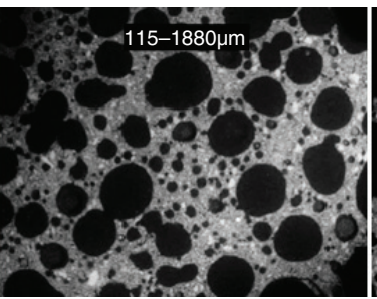

$0,15 \% \mathrm{H}_{2} \mathrm{O}_{2}$

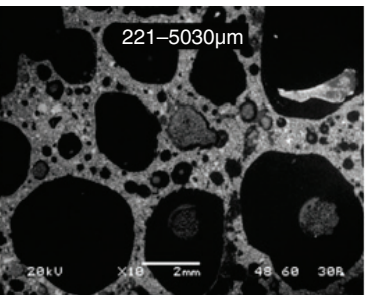

$0.25 \% \mathrm{H}_{2} \mathrm{O}_{2}$

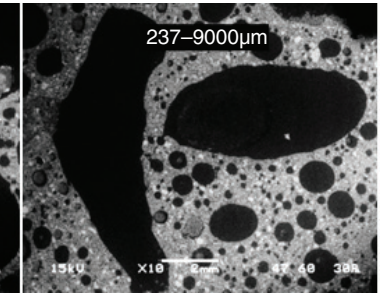

$1 \% \mathrm{H}_{2} \mathrm{O}_{2}$

(b) $4 \mathrm{M}$

FIGURE 4. Scanning Electron Microscopy images of geopolymer foam boards in function of increasing $\% \mathrm{H}_{2} \mathrm{O}_{2}$ in the geopolymer paste at constant for a) $2 \mathrm{M} \mathrm{NaOH}$ geopolymer foam board and b) $4 \mathrm{M} \mathrm{NaOH}$ geopolymer foam board (S/L: 2 g/mL Curing: $24 \mathrm{~h}$ at 70 and $96 \mathrm{~h}$ at $50^{\circ} \mathrm{C}$ ) 
a plateau of values is formatted confirming that higher addition of $\mathrm{H}_{2} \mathrm{O}_{2}$ does not affect the porosity of the final product.

Voids segmentation measurements of the full polished area of each board have been made and

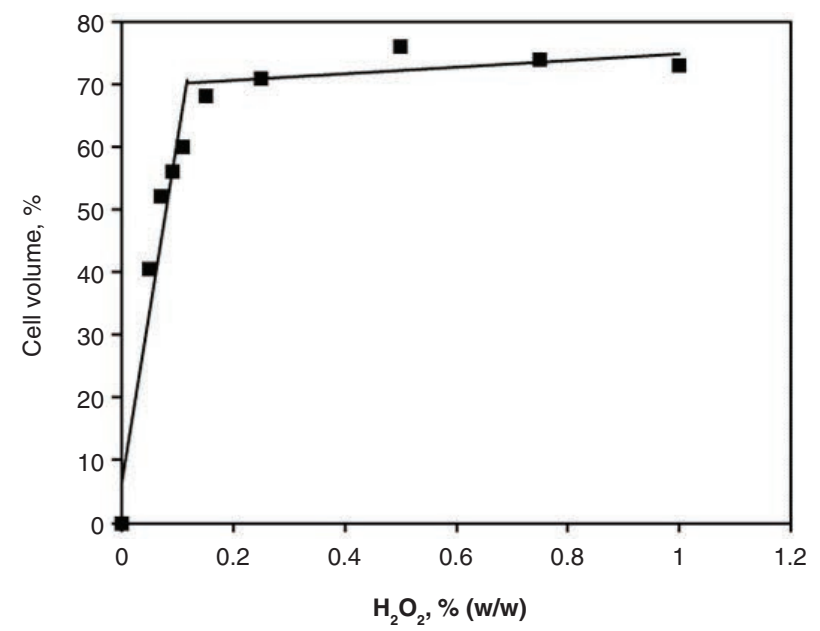

FIGURE 5. \% Cell Volume of geopolymer board as a function of the content of the foaming agent in the paste based on digital methods ([NaOH]: $2 \mathrm{M}, \mathrm{S} / \mathrm{L}: 2 \mathrm{~g} / \mathrm{mL}$, Curing: $24 \mathrm{~h}$ at 70 and $96 \mathrm{~h}$ at $50^{\circ} \mathrm{C}$ ). the results were summarized in a histogram. The two horizontal axes contain classes of void sizes as a function of increasing $\mathrm{H}_{2} \mathrm{O}_{2}$ content. These classes are normalized according to the total area of each sample. Vertical axis represents the frequency of each class in values of measured total area in $\mathrm{cm}^{2}$ of the detected voids. Data were divided in fifty classes and the most representative of them were selected to form the histogram which is given in Figure 6.

To enable visibility of low frequency values, the vertical axis of the histogram is presented after appropriate magnification for each class, which is needed in case of large size vesicles. As a general trend, samples with low concentration of $\mathrm{H}_{2} \mathrm{O}_{2}$ $(0.05-0.25 \%)$ exhibit a large number of independent, small voids (Class A). Further addition of the foaming agent $(0.25-1 \%)$ results to the formation of medium (Class B, C) and large bubbles (Class D). In this experimental series, the maximum concentration of $\mathrm{H}_{2} \mathrm{O}_{2}$ is $1 \%$, which mainly results in voids of large size (Class D). High $\mathrm{H}_{2} \mathrm{O}_{2}$ concentrations in the geopolymer matrix produce a smaller number of bubbles with larger volumes. This appears to be a result of the merging of many smaller bubbles into less larger ones, easily demonstrated by the SEM (Figure 4) and scanned images (Figure 1) of the final boards. These larger perforated voids which

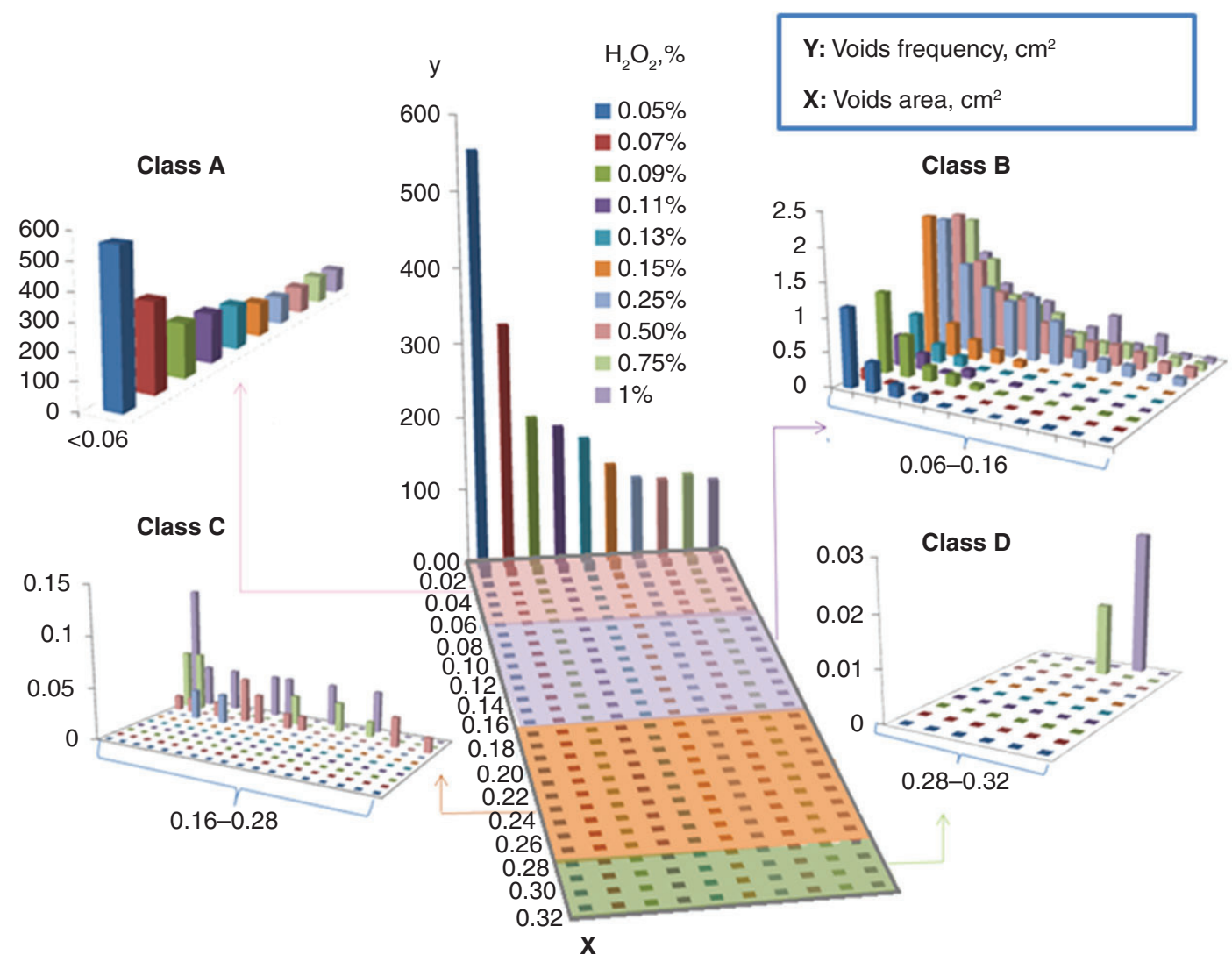

FIGURE 6. Histogram plot of the frequency of voids $/ \mathrm{cm}^{2}$ (vertical axis) against the distribution of the void sizes $\left(\operatorname{area}-\mathrm{cm}^{2}\right)$ (horizontal axis) in increasing $\mathrm{H}_{2} \mathrm{O}_{2}$ of the geopolymer board ([NaOH]: $2 \mathrm{M}, \mathrm{S} / \mathrm{L}: 2 \mathrm{~g} / \mathrm{mL}$, Curing: $24 \mathrm{~h}$ at 70 and $96 \mathrm{~h}$ at $50{ }^{\circ} \mathrm{C}$ ). 
clearly form from more circular voids, can also be detected as circles by the circle detection algorithm that was used in this study.

\section{CONCLUSIONS}

In this study, hydrogen peroxide $\left(\mathrm{H}_{2} \mathrm{O}_{2}\right)$ was selected for the foaming of the geopolymer paste. It was observed that the inorganic boards reached low apparent density values, presenting an optimum value $\left(408 \mathrm{~kg} / \mathrm{m}^{3}\right.$ and $\left.476.5 \mathrm{~kg} / \mathrm{m}^{3}\right)$ at $0.25 \%$ hydrogen peroxide content for $2 \mathrm{M}$ and $4 \mathrm{M}$ of $\mathrm{NaOH}$ concentartion respectively. Concerning thermal conductivity, the optimum value is aprox $0.075 \mathrm{~W} /$ $\mathrm{mK}$ in case of $2 \mathrm{M}$ and $0.09 \mathrm{~W} / \mathrm{mK}$ in case of $4 \mathrm{M}$. The compressive strength measurements revealed that geopolymer foams can achieve similar or even better values (3.66 $\mathrm{MPa}$ ) especially in comparison to the other conventional lightweight materials such as AAC and aerated concrete. The microstructure study of final boards revealed large non-homogeneous voids 128-9350 $\mu \mathrm{m}$ and rough but easy leveled surfaces. Digital methods were used for the estimation of frequency for specific voids sizes per $\mathrm{cm}^{2}$ of each sample in function of increasing $\mathrm{H}_{2} \mathrm{O}_{2}$. Results that were presented in a histogram confirmed that low $\mathrm{H}_{2} \mathrm{O}_{2}$ produces a high number of independent, small voids, while higher peroxide contents lead to bigger void sizes but less in number. Experimental and digital methods are in accordance with the formation of a plateau when peroxide exceeds the value of $0.25 \%$. In comparison with other lightweight materials, the optimum foam boards from perlite have similar apparent density and better thermal conductivity values than AAC blocks (optimum thermal conductivity $0.12 \mathrm{~W} / \mathrm{mK}$ for apparent density $450 \mathrm{~kg} / \mathrm{m}^{3}$ ) $(39,40)$ and in case of foam concrete (optimum thermal conductivity $0.1 \mathrm{~W} / \mathrm{mK}$ and compressive strength $0.5-1 \mathrm{MPa}$ for apparent density $400 \mathrm{~kg} / \mathrm{m}^{3}$ ) (40) they present higher compressive strength and thermal conductivity values for the same density.

\section{REFERENCES}

1. Hammond, G.P.; Jones, C.I. (2006) Inventory of (Embodied) Carbon \& Energy (ICE). Department of Mechanical Engineering. International Journal of Research in Engineering and Technology

2. http://www.perlite.org

3. http://www.eaaca.org

4. Svanholm, G. (1990) Pouring into molds with removable walls, stiffening, autoclaving US4902211 A

5. Holt, E.; Raivio. P. (2004) Use of gasification residues in aerated autoclaved concrete. Cem. Concr. Res. 35, 796-802. https://doi.org/10.1016/j.cemconres.2004.05.005

6. Jerman, M.; Keppert. M.; Vyborny, J.; Cerny, R. (2013) Hygric, thermal and durability properties of autoclaved aerated concrete. Construc. Build. Mat. 41, 352-35. https:// doi.org/10.1016/j.conbuildmat.2012.12.036

7. http://www.masoncontractors.org/2008/10/16/usingautoclaved-aerated-concrete-correctly
8. Mostafa, NY. (2005) Influence of air-cooled slag on physicochemical properties of autoclaved aerated concrete. Cem. Concr. Res 35, 1349-57. https://doi.org/10.1016/j. cemconres.2004.10.011

9. http://keu92.org/uploads/Search $\% 20$ engineering/Light $\%$ 20weight $\% 20$ concrete.pdf

10. https://theconstructor.org/concrete/foam-concrete-materials-properties-advantages-production/15921/

11. Giannopoulou, I. Dimas, D.; Maragos, I; Panias, D (2009) Utilization of metallurgical solid wastes/by-products for development of inorganic polymeric construction materials. Global NEST Journal 11, 127-136

12. Davidovits, J. (1994) Properties of geopolymer cements. In Proc. 1st international conference on alkaline cements and concretes (KievUkraine), 131-149

13. Sakkas, K.; Panias, D.; Nomikos, P.; Sofianos, A. (2014b) Potassium based geopolymer for passive fire protection of concrete tunnels linings. Tunnelling and Underground Space Technology 43, 148-56. https://doi.org/10.1016/j. tust.2014.05.003

14. Kamseu, E.; Nait-Ali, B.; Bignozzi, MC.; Leonelli, C.; Rossignol, S.; Smith, D.S. (2012) Bulk composition and microstructure dependence of effective thermal conductivity of porous inorganic polymer cements. J. Europ. Ceram. Soc. 32, 1593-603. https://doi.org/10.1016/j. jeurceramsoc. 2011.12.030

15. Zhang, Z.; Provis, J.; Reid, A.; Wang, H. (2014) Geopolymer foam concrete: An emerging material for sustainable construction. Construc. Build. Mat. 56, 113-127. https://doi. org/10.1016/j.conbuildmat.2014.01.081

16. Williams, B. H. (1928) The thermal decomposition of hydrogen peroxide in aqueous solutions. Faraday Soc. 24, 245-255. https://doi.org/10.1039/tf9282400245

17. Masi, G.; LesVickers, W.; Bignozzi, M-C.; Riessen, A. (2014) A comparison between different foaming methods for the synthesis of lightweight geopolymers. Ceram. Internat. 40 [9] Part A, 13891-13902. https://doi. org/10.1016/j.ceramint.2014.05.108

18. Wefers K. and Misra C. (1987) Oxides and Hydroxides of Aluminum: Technical Report 19-Revised. Alcoa Laboratories. Pittsburgh, 64-71

19. Tsaousi, G-M.; Douni, I.; Panias, D. (2016) Characterization of the properties of perlite geopolymer pastes. Mater. Construcc. 66[324]:e102. https://doi. org/10.3989/mc.2016.10415

20. Koschan, A.; Abidi, M. (2008) Digital color image processing. Wiley-Interscience. https://doi.org/10.1002/9780470 230367

21. Atherton, T. J.; Kerbyson, D.J. (1999) Size invariant circle detection. Image and Vision Computing 17, 795-803. https://doi.org/10.1016/S0262-8856(98)00160-7

22. Cuevas, E.; Wario, F.; Osuna- Enciso, V.; Zaldivar, D.; Pérez-Cirneros, M. (2012) Fast algorithm for multiplecircle detection on images using Learning Automata. IET Image Processing 6, 1124-1135.

23. Rad, A.A.; Faez, K.; Qaragozlou, N. (2003) Fast circle detection using gradient pair vectors. In Proc. VIIth Digital Image Computing: Techniques and Applications

24. Yuen, H.K.; Princen, J.; Illingworth, J.; Kittler, J. (1990) Comparative study of Hough transform methods for circle finding. Image and Vision Computing 8, 71-77. https://doi. org/10.1016/0262-8856(90)90059-E.

25. Illingworth, J.; Kittler, J. (1987) The Adaptive Hough Transform. IEEE Transactions on Pattern Analysis and Machine Intelligence 9 [5], 690-698. https://doi.org/10.1109/ TPAMI.1987.4767964

26. Illingworth, J.; Kittler, J. (1988) A survey of the Hough transform. Computer Vision, Graphics and Image Processing 44, 87-116. https://doi.org/10.1016/S0734-189X(88)80033-1

27. Pan, L.; Chu, W. S.; Saragih, M., J.; Torre, F. (2010) Fast and robust circular object detection with probabilistic pairwise voting (PPV). IEEE Signal Processing Letters 18, 639-642.

28. Chung, K.L.; Chen, T.C. (2001) An efficient randomized algorithm for detecting circles. Computer Vision and 
Image Understanding 83, 172-191. https://doi.org/10.1006/ cviu.2001.0923

29. Nambiar, E.K.; Ramamurthy, K. (2007) Air-void characterisation of foam concrete. Cem. Concr. Res 37 [2], 221-230. https://doi.org/10.1016/j.cemconres. 2006.10.009

30. Soutsos, M.; Boyle, A.P.; Vinai, R.; Hadjierakleous, A.; Barnett, S.J. (2016) Factors influencing the compressive strength of fly ash based geopolymers. Construc. Build. Mat. 110 [5], 355-368. https://doi.org/10.1016/j. conbuildmat.2015.11.045

31. Zhang, Z.; Provis, J.L.; Reid, A.; Wang, H. (2015) Mechanical, thermal insulation, thermal resistance and acoustic absorption properties of geopolymer foam concrete. Cem. Concr. Comp. 62:97-105. https://doi. org/10.1016/j.cemconcomp.2015.03.013

32. Ducman, V.; Korat, L. (2016) Characterization of geopolymer fly-ash based foams obtained with the addition of $\mathrm{Al}$ powder or $\mathrm{H}_{2} \mathrm{O}_{2}$ as foaming agents. Mat. Charac. 113 207-213. https://doi.org/10.1016/j. matchar.2016.01.019

33. Alengaram, U.J.; Al-Muhit, B.A.; Jumaat, M.Z.; Liu, M.Y.J. (2013) A comparison of the thermal conductivity of oil palm shell foamed concrete with conventional materials. Mat. Des. 51, 522-529. https://doi.org/10.1016/j. matdes.2013.04.078

34. Song, Y.; Li, B.; Yang, E.H.; Liu, Y.; Ding, T. (2015) Feasibility study on utilization of municipal solid waste incineration bottom ash as aerating agent for the production of autoclaved aerated concrete. Cem. Concr. Comp. 56, 51-58. https://doi.org/10.1016/j.cemconcomp.2014.11.006

35. Torres, M.L.; García-Ruiz, P.A. (2009) Lightweight pozzolanic materials used in mortars: Evaluation of their influence on density, mechanical strength and water absorption. Cem. Concr. Comp. 31, 114-119. https://doi.org/10.1016/j. cemconcomp.2008.11.003

36. Yong Jing Lia, M.; Alengaram, U.J.; Santhanam, M.; Jumaat, M.Z.; Hung Mo, K. (2016) Microstructural investigations of palm oil fuel ash and fly ash based binders in lightweight aggregate foamed geopolymer concrete. Construc. Build. Mat. 120:112-122. https://doi. org/10.1016/j.conbuildmat.2016.05.076

37. Vaou, V.; Panias, D. (2010) Thermal insulating foamy geopolymers from perlite. Minerals Engineering 23, 1146-51. https://doi.org/10.1016/j.mineng.2010.07.015

38. Tsaousi, G-M.; Douni, I.; Taxiarchou, M.; Panias. D.; Paspaliaris, I. (2014) Development of foamed Inorganic Polymeric Materials based on Perlite. IOP Conference Series: Materials Science and Engineering 123. https://doi. org/10.1088/1757-899X/123/1/012062

39. Newman, J.; Owens, P. (2013) Properties of lightweight concrete. In: Newman J, Choo RS, editors. Advanced concrete technology Part 3: process. Butterworth-Heinemann Press; $2 / 7-2 / 9$

40. Hamad, A.J. (2014) Materials, Production, Properties and Application of Aerated Lightweight Concrete: Review. Int. J. Mat. Sci. Eng. 2, 152-157. https://doi.org/10.12720/ ijmse.2.2.152-157 